.... Albrektas, Revuckaitè, Dobilaitè, Juciene: Influence of Finishing Materials on Viscous ...

\title{
Influence of Finishing Materials on Viscous Elastic Properties of Wooden Structures
}

\section{Utjecaj premaznih materijala na viskoelastična svojstva drvenih elemenata}

Preliminary paper • Prethodno priopćenje

Received-prispjelo: 19. 4. 2018.

Accepted-prihvaćeno: 10. 12. 2018.

UDK: $630 * 812.703 ; 630 * 812.751 ; 630 * 829$

doi: $10.5552 /$ drvind.2019.1816

\begin{abstract}
In this study, the effect of finishing process on the mechanical properties of oak and pine wood elements were investigated. A special test stand was used for this purpose. Specimens were divided into subgroups, the resonance frequency of the specimens was determined (when they vibrate in mode of a theoretic isotope beam), and the modulus of elasticity (MOE) and damping coefficient were estimated. It was determined that MOE of oak and pine specimens was 8415-10570 MPa and 8220-14104 MPa, respectively, while damping coefficients were 0.014-0.019 r. u. and 0.013-0.026. Afterwards, some specimens were varnished (pentaftal varnish was used), while the specimens from others subgroups were oiled (water-based outdoor wood oil was used) and after each processing step, the viscous elastic properties of the specimen were recorded. The specimens were finished four times - first, one side was finished in two layers, and then the other side. For the determination of elastic properties of the finishing materials, films were prepared separately. The film formation was carried out by casting liquid on a smooth, siliconised surface of a test panel. The tensile test was carried out using the universal testing machine. It was established that MOE of films varied in the range of 4-7 MPa. After the varnishing process, the MOE of oak and pine elements decreased by $5 \%$ and $7 \%$, respectively, while the damping coefficient decreased (in varnish case) by $60 \%$. The impact of oil on viscous elastic properties of the specimens was quite marginal.
\end{abstract}

Keywords: oak wood, pine wood, modulus of elasticity, damping coefficient, finishing materials, pentaftal varnish, wood oil

SAŽETAK • U radu je istraživan utjecaj procesa površinske obrade na mehanička svojstva hrastovine i borovine. Za istraživanje je pripremljeno posebno postolje. Uzorci su podijeljeni u dvije podskupine, utvrđena je njihova rezonantna frekvencija (kada vibriraju u modu teorijskog snopa izotopa) te su procijenjeni modul elastičnosti (MOE) i koeficijent prigušenja uzoraka. Utvrđeno je da je MOE uzoraka od hrastovine 8415 - 10570 MPa, uzoraka od borovine 8220 - $14104 \mathrm{MPa}$, a koeficijent prigušenja iznosio je 0,014-0,019 r. u., odnosno 0,013-0,026. Nakon toga dio uzoraka je lakiran (upotrijebljen je pentaftalni lak), a uzorci iz druge podskupine premazani su uljem (uljem na bazi vode za vanjsku primjenu). Nakon svakog procesa obrade uočena su viskoelastična svojstva uzoraka. Uzorci su premazani ukupno četiri puta - najprije je u dva sloja premazana jedna, a zatim druga strana uzoraka. Za određivanje elastičnih svojstava premaznih materijala posebno su pripremljeni filmovi, i to nalijevanjem premaznog materijala na glatku, silikoniziranu površinu ispitne ploče. Vlačno ispitivanje obavljeno je na

\footnotetext{
${ }^{1}$ Authors are associate professor and student at Kaunas University of Technology, Faculty of Mechanical Engineering and Design, Kaunas, Lithuania. ${ }^{2}$ Authors are researchers at Kaunas University of Technology, Institute of Architecture and Construction, Kaunas, Lithuania.

Autori su izvanredni profesor i student Tehničkog sveučilišta u Kaunasu, Fakultet strojarstva i dizajna, Kaunas, Litva.

${ }^{2}$ Autori su istraživači Tehničkog sveučilišta u Kaunasu, Institut za arhitekturu i graditeljstvo, Kaunas, Litva.
} 
univerzalnom uređaju za mehanička ispitivanja. Utvrđeno je da MOE filmova varira u rasponu od 4 do 7 MPa. Nakon lakiranja MOE hrastovih elemenata smanjio se za $5 \%$, borovih elemenata za $7 \%$, a koeficijent prigušenja na lakiranim uzorcima smanjio se za $60 \%$. Ulja su neznatno utjecala na viskoelastična svojstva uzoraka.

Ključne riječi: hrastovina, borovina, modul elastičnosti, koeficijent prigušenja, premazni materijali, pentaftalni lak, ulje za drvo

\section{INTRODUCTION}

\section{UVOD}

The elements of wood and wood-based materials are widely used in building structures and interior products. The durability of wood for outdoor use is not only affected by climatic factors but also by mechanical properties of wood, which to a large extent depend on the finish. The complex effect of the mechanical and physical properties of wood and environmental factors determines the durability of wooden structures and other wood-based products. Depending on the purpose, wooden structures must exhibit appropriate mechanical properties, which are often subject to legislation, building regulations and standards. In some cases, the structures must be elastic and resistant to various mechanical loads, in other cases, on the contrary, they must be able to dampen vibrations and sounds, as well as have inhibitory properties (Forssén et. al., 2008; Botterman et. al., 2018).

The mechanical properties of these kinds of structures are determined by the mechanical properties of their individual elements and the composition method of their interconnection (Taghiyari et al., 2017; Souza da Rosa et. al., 2017; Albrektas and Vobolis, 2003; Albrektas and Vobolis, 2004). It is known that the modulus of elasticity (MOE) and damping coefficient of a glued wood panel depends on the properties of the glued wood scantlings (Albrektas and Vobolis, 2003; Albrektas and Vobolis, 2004). Once a scantling, which is characterised by a higher MOE, is glued to the panel, the MOE of the whole panel becomes higher, and vice versa. A lower MOE and a higher damping coefficient of the glued product than the average value of the total number of glued scantlings show that the product probably contains defects, e.g. that the seams were poorly glued together, etc.

The viscous elastic properties of the elements of wooden structures can be altered, e.g. by changing the surface area of the element (i.e. by creating grooves, notches, etc.) (Ono, 1993; Molin et. al., 1984; Molin et. al., 1988), by soaking them (Endo et. al., 2010) and using finishing materials of different properties.

It was determined that different components of wooden composites and manufacturing technology can also have an effect on their mechanical properties (Taghiyari et al., 2017).

Also, overlays have a large effect on the mechanical properties of particleboard (Vobolis and Albrektas, 2012). Depending on the orientation/direction of the overlay material (especially on sliced veneer of natural wood), the MOE of a finished particleboard can be increased or decreased in the direction concerned. This can be explained by the fact that the viscous elastic properties of natural wood can vary up to 20 times in different fibre directions.

Nowadays, the market offers various finishing materials of wood. Therefore, there is a lack of comprehensive research that evaluates the influence of finishing materials on the properties of wood-based products.

The aim of this study is to evaluate the influence of finishing materials on viscous elastic properties of wooden structures and their elements.

\section{MATERIALS AND METHODS 2. MATERIJALI I METODE}

The research study used conditioned specimens of oak (Quercus robur) and pine (Pinus sylvestris) wood, which were stored in a climatic chamber for 336 hours at a temperature of $20 \pm 1{ }^{\circ} \mathrm{C}$, and a relative humidity of $60 \pm 2 \%$ (standard EN 408, chapter 8 ). The dimensions of the researched specimens were $700 \mathrm{~mm}$ $\times 100 \mathrm{~mm} \times 16 \mathrm{~mm}$, with moisture content ranging between 10.4 and $11.2 \%$ (standard EN 13183-2). According to the standard EN 323, the density of the specimens was measured and the results showed that oak wood had a density ranging between 650 and 760 $\mathrm{kg} / \mathrm{m}^{3}$, whereas the density of pine wood ranged between 460 and $570 \mathrm{~kg} / \mathrm{m}^{3}$.

For finishing the specimens, two types of material were used: pentaftal varnish and water-based outdoor wood oil, based on water and natural oils. The amount of non-volatile substances of the varnish is 46 $\pm 3 \%$, whereas the amount of non-volatile substances of the oil is $21 \%$. The pentaftal varnish, which is based on alkyd resins, covers the wood surface with an elastic film that suppresses liquids; however, it allows steam to penetrate and it is resistant to atmospheric agents. The water-based wood oil soaks into the wood surface and serves as protection from humidity and dirt.

A special test stand (Figure 1) was used to determine the MOE and damping coefficient on the basis of non-destructive testing (transverse resonant vibrations) method, which also allowed assessing the mechanical properties of the specimens (Albrektas and Vobolis, 2003; Albrektas and Vobolis, 2004). Loudspeaker 4, controlled by the generator of electric oscillations 5 , excites resonance oscillations of the specimen 1. For this purpose, the frequency of the generator's oscillations is changed. These oscillations are recorded by the sensor 6, fixed on the specimen. Their amplitude is measured using device 7. To ascertain the direction of specimen bending, the phase of oscillations is measured by a phase meter 9 . The phase meter receives the signal from the measuring device and generator. For a more accurate ascertainment of the form of bending, several zones of specimen were chosen. In these zones 


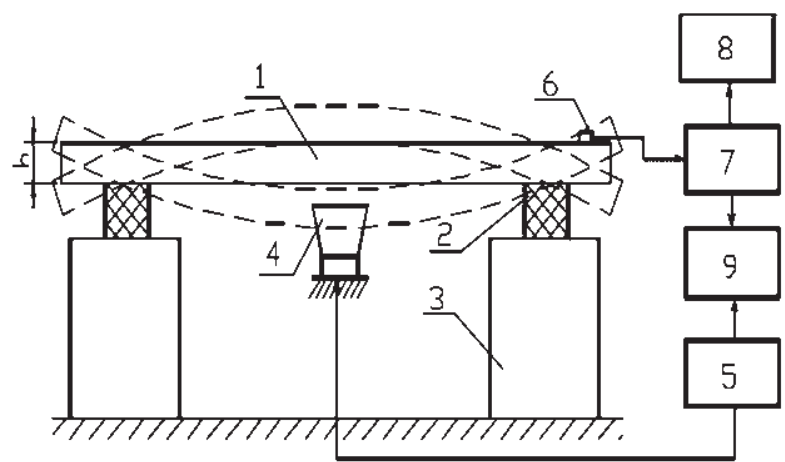

Figure 1 Scheme of test stand:1 - specimen; 2 - vibration damping material (foam rubber); 3 - massive supports; 4 - loudspeaker; 5 - vibration generator; 6 - sensor; 7 measuring instrument; 8 - oscilloscope; 9 - phase meter Slika 1. Shema ispitnog postolja: 1 - uzorak; 2 - materijal za prigušivanje vibracija (pjenasta guma); 3 - masivni nosači; 4 - zvučnik; 5 - generator vibracija; 6 - senzor; 7 - mjerni instrument; 8 - osciloskop; 9 - fazni mjerač

the measuring element was fixed and oscillations were recorded, i.e. their amplitude and phase were measured. By determining the corresponding (first mode) frequency, a MOE is calculated. By determining two other frequencies, when the vibrational amplitude decreases by 0.7 times, the damping coefficient is calculated. The studies were performed at a frequency of 20-2000 Hz.

The MOE was calculated by the following Eq. 1 (Timoshenko et al., 1985):

$$
E=\frac{f_{\mathrm{rez}}^{2} \cdot 4 \pi^{2} \cdot \rho \cdot s \cdot l^{4}}{I \cdot A^{2}}
$$

Where: $E$ - modulus of elasticity, $f_{\text {rez }}$ - frequency of transverse vibrations, $\rho$ - density of wood, $s-$ crosssectional area, $l$ - beam length, $I$ - cross-sectional moment of inertia, $A$ - method of fastening represented by a coefficient.

The viscous properties of studied specimens were evaluated by damping coefficient, calculated by the following Eq. 2:

$$
\operatorname{tg} \delta \approx \frac{\Delta f}{f_{\text {rez }}}
$$

Where: $f_{\text {rez }}$ - frequency of transverse vibrations, $\Delta f-$ frequency bandwidth, when the amplitude of vibrations decreases by 0.7 times.

In order to evaluate the influence of finishing materials on viscous-elastic properties of wooden structures, the specimens were covered with two types of products for wooden surfaces. The finishing materials were applied to the specimens following the recommendations of the manufacturers. Prior to application, the specimens were stored at $23 \pm 2{ }^{\circ} \mathrm{C}$ temperature and $50 \pm 5 \%$ relative humidity for $24 \mathrm{~h}$. The surface of the specimen intended for covering was clean and free from distortion and other defects. The finishing material was applied with a brush in 2 layers (stepwise) on both sides of the specimen. After each application of the layer, the specimen was dried for 24 hours under the above temperature/humidity conditions in accordance with manufacturer's instructions without prejudice to EN 23270.

For the determination of elastic properties of finishing materials, films were prepared separately, consisting of wood varnish and oil, which were used for the study. The film was formed by casting liquid on a smooth, siliconised surface of a test panel. The casting was dried for 7 days at $23 \pm 2{ }^{\circ} \mathrm{C}$ temperature and $50 \pm$ $5 \%$ relative air humidity. The film formation process was completed by removing it from the test surface. Afterwards, the film-coated specimens were cut to determine the modulus of elasticity. Ten specimens of varnish and the same number of oil specimens were cut for tensile test. The uniformity of film specimens was ensured by measuring the thickness, which was on average $0.30 \mathrm{~mm}$ in the case of varnish and $0.19 \mathrm{~mm}$ in the case of oil. The tensile test was carried out using the universal testing machine BTI FB-050 TN (Zwick). The gripping distance was $100 \mathrm{~mm}$ and the constant speed for the grips was $100 \mathrm{~mm} / \mathrm{min}$.

\section{RESULTS AND DISCUSSION} 3. REZULTATI I RASPRAVA

After completing the conditioning process, the specimens were divided into subgroups (oak specimens were divided into $\mathrm{O} .1$ and 0.2 , whereas pine specimens were divided into P.1 and P.2), the resonance frequency of the specimens was determined (when they vibrate in mode of a theoretic isotope beam) (Timoshenko et al., 1985), and the MOE and damping coefficient were estimated. The results are displayed in Table 1.

The estimated values of the MOE and damping coefficient of wood correspond to the values that are well-known in literature (Wagenführ, 2000; Wood Handbook, 2010).

The analysis of the viscous properties of the finishing films showed that the MOE of wood varnish and oil varies in the range of 4-7 $\mathrm{MPa}$ with a variation of

Table 1 Values of resonance frequency, MOE and damping coefficient of specimens before finish was applied

Tablica 1. Vrijednosti rezonantne frekvencije, modula elastičnosti i koeficijenta prigušenja uzoraka prije površinske obrade

\begin{tabular}{|c|c|c|c|c|c|c|}
\hline \multirow{2}{*}{$\begin{array}{c}\text { Subgroup } \\
\text { Podskupina }\end{array}$} & \multicolumn{2}{|c|}{$\begin{array}{c}\text { Resonance frequency, } \mathrm{Hz} \\
\text { Rezonantna frekvencija, Hz }\end{array}$} & \multicolumn{2}{|c|}{ MOE, MPa } & \multicolumn{2}{c|}{$\begin{array}{c}\text { Damping coefficient, r. u. } \\
\text { Koeficijent prigušenja, r. u. }\end{array}$} \\
\cline { 2 - 7 } & Min & Max & Min & Max & Min & Max \\
\hline O.1 & 114 & 142 & 8415 & 10570 & 0.014 & 0.031 \\
\hline O.2 & 118 & 130 & 8520 & 10010 & 0.016 & 0.019 \\
\hline P.1 & 132 & 176 & 8220 & 14104 & 0.013 & 0.026 \\
\hline P.2 & 136 & 159 & 8650 & 12430 & 0.013 & 0.017 \\
\hline
\end{tabular}




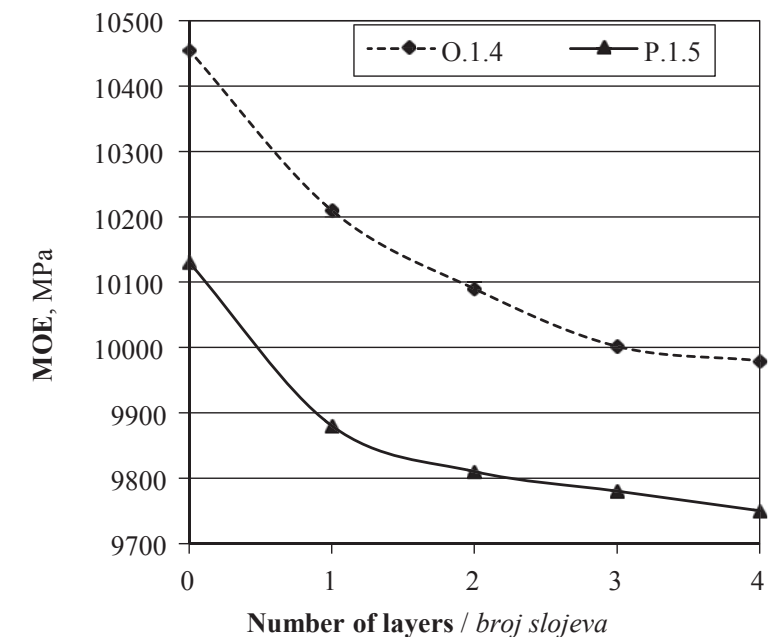

a)

Figure 2 Variations of specimens MOE by increasing the number of layers of the finishing material: a) varnish finish; b) oil finish; these are unique identification numbers of specimens -O.1.4, P.1.5, O.2.7, P.2.10.

Slika 2. Varijacije modula elastičnosti uzoraka s povećanjem broja slojeva premaznog materijala: a) lak; b) ulje; oznake uzoraka su O.1.4, P.1.5, O.2.7, P.2.10.

$10.6 \%$. These values correspond to the values that are well-known in literature (Mironeet et al., 2004; Ghaznavi et. al., 2013; Wawro and Kazimierczak, 2008).

Afterwards, the specimens from subgroups 0.1 and P.1 were varnished, while the specimens from subgroups 0.2 and P.2 were oiled using the test finishing materials, and after each processing step, the viscous elastic properties of the specimen were recorded. Each subgroup is appropriately represented by the variation of the MOE and damping coefficient of the specimens in Figures 2 and 3.

The values of the mechanical properties of all the specimens before and after the finishing treatment are provided in Tables 2 and 3 .

According to these results (Table 2), it was estimated that between the minimum and maximum value in the same group of specimens, the MOE of oak wood specimens before and after varnish finish can vary up to $23 \%$, whereas the results before and after oil finish show that the difference between the maximum and

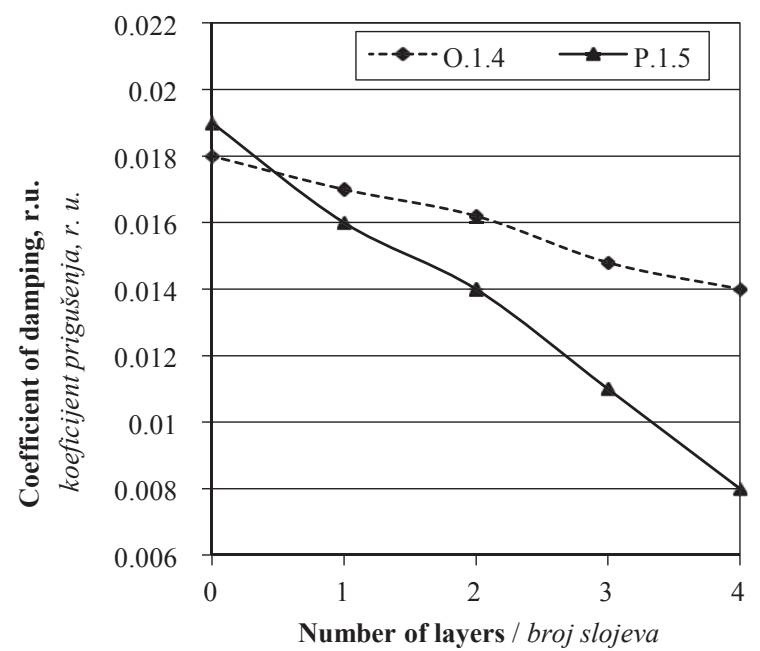

a)

Figure 3 Variations of damping coefficient of specimens by increasing the number of layers of the finishing material: a) varnish finish; b) oil finish

Slika 3. Varijacije koeficijenta prigušenja uzoraka s povećanjem broja slojeva premaznog materijala: a) lak; b) ulje minimum value is no larger than $15 \%$. Before using the varnish finish on oak wood specimens, the values of the damping coefficient in the same group can vary more than $50 \%$. After using the varnish finish, the difference between the minimum and maximum damping coefficient was reduced to $37 \%$. The use of this finishing treatment reveals that the damping coefficient of the specimens was reduced in all cases. The outcome was a little different in the group that was treated with oil finish. After applying the oil finish, the damping ratio was practically left unchanged, and in some cases, the results showed a slight increase or decrease.

The equivalent results were retrieved by analysing the tests results of pine wood specimens. The use of oil finish on pine wood specimens proved to have no effect on the damping coefficient, since in nine out of ten cases, after applying the oil finish, the damping coefficient of the specimens remained unchanged.

It was determined that, after the varnishing process, the mass of oak wood specimens increased by 9-14

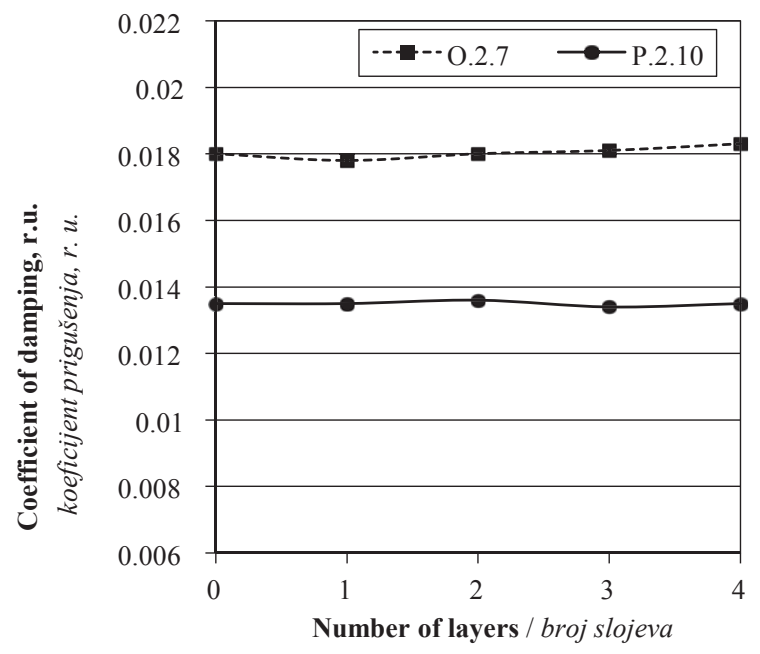

b) 
Table 2 Mechanical properties of oak wood specimens before and after the finishing treatment

Tablica 2. Mehanička svojstva uzoraka hrastovine prije i nakon površinske obrade

\begin{tabular}{|c|c|c|c|c|c|c|c|c|c|}
\hline \multirow{2}{*}{$\begin{array}{l}\text { Specimen } \\
\text { No. } \\
\text { Broj } \\
\text { uzorka }\end{array}$} & \multicolumn{2}{|c|}{ MOE, MPa } & \multicolumn{2}{|c|}{$\begin{array}{l}\text { Damping coefficient, } \\
\text { r. u. } \\
\text { Koeficijent prigušenja, } \\
\text { r. u. }\end{array}$} & \multirow{2}{*}{$\begin{array}{c}\text { Speci- } \\
\text { men No. } \\
\text { Broj } \\
\text { uzorka }\end{array}$} & \multicolumn{2}{|c|}{ MOE, MPa } & \multicolumn{2}{|c|}{$\begin{array}{l}\text { Damping coefficient, } \\
\text { r. u. } \\
\text { Koeficijent prigušenja, } \\
\text { r. u }\end{array}$} \\
\hline & $\begin{array}{c}\text { Before } \\
\text { varnish } \\
\text { finish } \\
\text { Prije } \\
\text { lakiranja }\end{array}$ & $\begin{array}{c}\text { After } \\
\text { varnish } \\
\text { finish } \\
\text { Nakon } \\
\text { lakiranja }\end{array}$ & $\begin{array}{c}\text { Before } \\
\text { varnish } \\
\text { finish } \\
\text { Prije } \\
\text { lakiranja }\end{array}$ & $\begin{array}{c}\text { After } \\
\text { varnish } \\
\text { finish } \\
\text { Nakon } \\
\text { lakiranja }\end{array}$ & & $\begin{array}{l}\text { Before } \\
\text { oil finish } \\
\text { Prije } \\
\text { uljenja }\end{array}$ & $\begin{array}{l}\text { After oil } \\
\text { finish } \\
\text { Nakon } \\
\text { uljenja }\end{array}$ & $\begin{array}{l}\text { Before oil } \\
\text { finish } \\
\text { Prije } \\
\text { uljenja }\end{array}$ & $\begin{array}{l}\text { After oil } \\
\text { finish } \\
\text { Nakon } \\
\text { uljenja }\end{array}$ \\
\hline 0.1 .1 & 9733 & 9380 & 0.031 & 0.017 & 0.2 .1 & 9505 & 9215 & 0.018 & 0.019 \\
\hline O.1.2 & 8655 & 8390 & 0.030 & 0.017 & 0.2 .2 & 8945 & 8610 & 0.017 & 0.018 \\
\hline O.1.3 & 10010 & 9720 & 0.023 & 0.012 & O.2.3 & 9775 & 9420 & 0.017 & 0.018 \\
\hline O.1.4 & 10455 & 9980 & 0.023 & 0.019 & O.2.4 & 8652 & 8550 & 0.018 & 0.018 \\
\hline 0.1 .5 & 9352 & 8883 & 0.018 & 0.014 & 0.2 .5 & 9595 & 9230 & 0.019 & 0.020 \\
\hline O.1.6 & 8415 & 8002 & 0.017 & 0.014 & O.2.6 & 8883 & 8790 & 0.018 & 0.018 \\
\hline 0.1 .7 & 10570 & 10357 & 0.014 & 0.012 & 0.2 .7 & 10010 & 9875 & 0.018 & 0.018 \\
\hline O.1.8 & 8942 & 8758 & 0.025 & 0.017 & O.2.8 & 8995 & 8850 & 0.018 & 0.018 \\
\hline O.1.9 & 10251 & 10040 & 0.015 & 0.012 & 0.2 .9 & 8520 & 8350 & 0.019 & 0.018 \\
\hline O.1.10 & 9522 & 9320 & 0.016 & 0.014 & O.2.10 & 8811 & 8720 & 0.016 & 0.017 \\
\hline
\end{tabular}

Table 3 Mechanical properties of pine wood specimens before and after finishing

Tablica 3. Mehanička svojstva uzoraka borovine prije i nakon površinske obrade

\begin{tabular}{|c|c|c|c|c|c|c|c|c|c|}
\hline \multirow{2}{*}{$\begin{array}{c}\text { Speci- } \\
\text { men No. } \\
\text { Broj } \\
\text { uzorka }\end{array}$} & \multicolumn{2}{|c|}{ MOE, MPa } & \multicolumn{2}{|c|}{$\begin{array}{l}\text { Damping coefficient, } \\
\text { r. u. } \\
\text { Koeficijent prigušenja, } \\
\text { r. u. }\end{array}$} & \multirow{2}{*}{\begin{tabular}{|} 
Specimen \\
No. \\
Broj \\
uzorka
\end{tabular}} & \multicolumn{2}{|c|}{ MOE, MPa } & \multicolumn{2}{|c|}{$\begin{array}{l}\text { Damping coefficient, } \\
\text { r. u. } \\
\text { Koeficijent prigušenja, } \\
\text { r. u }\end{array}$} \\
\hline & $\begin{array}{c}\text { Before } \\
\text { varnish } \\
\text { finish } \\
\text { Prije } \\
\text { lakiranja }\end{array}$ & $\begin{array}{c}\text { After } \\
\text { varnish } \\
\text { finish } \\
\text { Nakon } \\
\text { lakiranja }\end{array}$ & $\begin{array}{c}\text { Before } \\
\text { varnish } \\
\text { finish } \\
\text { Prije } \\
\text { lakiranja }\end{array}$ & $\begin{array}{c}\text { After } \\
\text { varnish } \\
\text { finish } \\
\text { Nakon } \\
\text { lakiranja }\end{array}$ & & $\begin{array}{l}\text { Before oil } \\
\text { finish } \\
\text { Prije } \\
\text { uljenja }\end{array}$ & $\begin{array}{l}\text { After oil } \\
\text { finish } \\
\text { Nakon } \\
\text { uljenja }\end{array}$ & $\begin{array}{l}\text { Before oil } \\
\text { finish } \\
\text { Prije } \\
\text { uljenja }\end{array}$ & $\begin{array}{l}\text { After oil } \\
\text { finish } \\
\text { Nakon } \\
\text { uljenja }\end{array}$ \\
\hline P.1.1 & 14104 & 13790 & 0.017 & 0.011 & P.2.1 & 9320 & 9305 & 0.014 & 0.014 \\
\hline P.1.2 & 11810 & 11500 & 0.019 & 0.013 & P.2.2 & 12430 & 12425 & 0.013 & 0.022 \\
\hline P.1.3 & 13260 & 12950 & 0.019 & 0.013 & P.2.3 & 9290 & 9305 & 0.014 & 0.014 \\
\hline P.1.4 & 12720 & 12450 & 0.015 & 0.010 & P. 2.4 & 8880 & 8830 & 0.016 & 0.016 \\
\hline P.1.5 & 10130 & 9750 & 0.019 & 0.008 & P.2.5 & 8725 & 8705 & 0.014 & 0.014 \\
\hline P.1.6 & 9082 & 8450 & 0.013 & 0.007 & P.2.6 & 12210 & 12190 & 0.015 & 0.015 \\
\hline P.1.7 & 13070 & 12130 & 0.013 & 0.009 & P.2.7 & 11510 & 11480 & 0.013 & 0.013 \\
\hline P.1.8 & 9687 & 9315 & 0.026 & 0.019 & P.2.8 & 8950 & 8915 & 0.015 & 0.015 \\
\hline P.1.9 & 8220 & 8045 & 0.015 & 0.011 & P.2.9 & 8650 & 8625 & 0.017 & 0.017 \\
\hline P.1.10 & 15050 & 14210 & 0.024 & 0.012 & P.2.10 & 10250 & 10270 & 0.014 & 0.014 \\
\hline
\end{tabular}

- the maximum group value / najveća vrijednost skupine, - the minimum group value / najmanja vrijednost skupine

$\mathrm{g}$ (on average approximately $1.5 \%$ of the specimen mass). In all cases, the MOE decreased by $1-5 \%$, whereas the damping coefficient decreased by $15-50 \%$.

The results show that the mass of the varnished pine wood specimens increased by $13-21 \mathrm{~g}$ (on average approximately $3.3 \%$ of the specimen mass). A higher mass change also implied a change in the mechanical properties of the specimens - the MOE decreased by $2-7 \%$, while the damping coefficient decreased by $30-$ $60 \%$. Pine wood could absorb more varnish, since it has a lower density and its capillary system can encompass a higher relative volume of the whole specimen.

It was established that the mass of the oiled oak wood specimens increased by $7 \mathrm{~g}$, while in the case of pine, it increased by only $4 \mathrm{~g}$, i.e. it altered less than 1 $\%$ of the specimen mass. It can be assumed that the impact of oil on the viscous elastic properties of the specimens was quite marginal. The MOE of oak specimens decreased by 1-4\%, the damping coefficient increased by $5 \%$, whereas the MOE and damping coefficient of pine specimens were ultimately left unchanged - the values varied within a $1 \%$ range.

A clear reliance of the impact of the finishing material on a varied density of the same type of specimens was not determined. Also, there is no evidence of a linear relationship between the amount of finishing material for the specimen finishing procedure and the change of the viscous elastic properties. Moreover, there was also the influence of other factors, such as the uniformity of coating thickness of the finish, the depth of penetration, etc.

The decrease of the MOE of the finished specimens can be explained by taking into account that the 
MOE of the finishing materials is significantly lower (4-7 $\mathrm{MPa}$ ) than that of natural wood (8220-14104 $\mathrm{MPa}$ ) (Table 1). Furthermore, the finishing materials, especially varnish, can improve the acoustic properties of wood elements (Ono, 1993).

\section{CONCLUSIONS}

4. ZAKLJUČAK

It was established that the finishing materials can alter the viscous elastic properties of wooden structure elements. Moreover, this effect is proportional to the amount of used material but not directly depend on the mass of the finishing materials. When the varnish formed $2 \%$ (oak) - $5 \%$ (pine) of sample mass, the MOE decreased by 5-7 percent, respectively. The damping coefficient in these cases decreased to 30-60 percent. The oil formed a smaller part of the specimen and its influence on mechanical properties was lower.

It was estimated that the finishing material (oil and varnish) amounted to a considerable fraction of the total mass of the finished specimen (at least $1.5 \%$ ), and in all cases, its modulus of elasticity and damping coefficient decreased. This can be explained by the fact that the modulus of elasticity of finishing material is lower in relation to wood lengthwise fibre.

It was determined that a substantial amount of the finishing material (varnish) can improve the acoustic properties of a wooden element. An unvarnished wooden structure can dampen the sound more effectively than a varnished one.

\section{REFERENCES}

\section{LITERATURA}

1. Albrektas, D.; Vobolis, J., 2003: Investigation of mechanical parameters and defects of solid wood glued panels. Materials science. Kaunas University of Technology, Academy of Sciences of Lithuania, 9 (4): 368-373.

2. Albrektas, D.; Vobolis, J., 2004: Modelling and study of glued wood panel. Materials science. Kaunas University of Technology, Academy of Sciences of Lithuania, Kaunas. Technologija, 10 (4): 370-373.

3. Botterman, B.; Doudart de la Grée, G. C. H.; Hornikx, M. C. J.; Yu; Q. L; Brouwers, H. J. H., 2018: Modelling and optimization of the sound absorption of wood-wool cement boards. Applied Acoustics, 129: 144-154. https://doi.org/10.1016/j.apacoust.2017.07.017.

4. Endo, R.; Kamei, K.; Iida, I.; Yokoyama, M.; Kawahara, Y., 2010: Physical and mechanical properties of waterlogged wood treated with hydrolyzed feather keratin. Journal of Archaeological Science, 37: 1311-1316. https://doi.org/10.1016/j.jas.2009.12.034.

5. Forssén, J.; Kropp, W.; Brunskog, J.; Ljunggren, S.; Bard, D.; Sandberg, G.; Ljunggren, F.; Ågren, A.; Hallström, O.; Dybro, H.; Larsson, K.; Tillberg, K.; Jarnerö, K.;Sjökvist, L.-G.; Östman, B.; Hagberg, K.; Bolmsvik, A.; Olsson, A.; Ekstrand, C.-G.; Johansson, M., 2008: Acoustics in wooden buildings. State of the art 2008. Vinnova project 2007-01653. SP Rapport 2008: 16. SP Technical Research Institute of Sweden, Stockholm.

6. Ghaznavi, M.; Rostamisani, A.; Roohnia, M.; Jahanlatibari, A.; Yaghmaeipour, A., 2013: Traditional Varnishes and Acoustical Properties of Wooden Soundboards. Science International, 1 (12): 401-407.

https://doi.org/10.17311/sciintl.2013.401.407.
7. Mirone, G.; Marton, B.; Vancso, J., 2004: Elastic modulus profiles in the cross sections of drying alkyd coating films: modelling and experiments. European Polymer Journal, 40 (3): 549-560. https://doi.org/10.1016/j.eurpolymj.2003.10.017.

8. Molin, N. E.; Lindgren, L. E., 1988: Parameters of Violin Plates and their Influence on the Plate Modes. Journal Acoustical Society America, 83 (1): 281-291. https://doi.org/10.1121/1.396430.

9. Molin, N. E.; Tinnsten, T.; Wiklund, U.; Jansson, E. V., 1984: FEM - Analysis of an Orthotropic Shell to Determine Material Parameters of Wood and Vibration Modes of Violin Plates. STL - QPSR, 4: 11-37.

10. Ono, T., 1993: Effects of varnishing on acoustical characteristics of wood used for musical instrument soundboards. Journal of Acoustical Society of Japan (E), 14 (6): 397-407. https://doi.org/10.1250/ast.14.397.

11. Souza da Rosa, T.; Schweitzer, V. R.; Trianoski, R.; Iwakiri, S., 2017: Physical and mechanical properties of oriented wood-cement boards produced with five eucalyptus species FLORESTA. Curitiba, PR, 47 (3): 317-322. https://doi.org/10.5380/rf.v47i3.50789.

12. Taghiyari, H. R.; Taheri, A.; Omrani, P., 2017: Correlation between acoustic and physical-mechanical properties of insulating composite boards made from sunflower stalk and wood chips. European Journal of Wood and Wood Products. 75: 409-418. https://doi.org/10.1007/s00107-016-1101-7.

13. Timoshenko, S. P.; Young, D. H.; Weaver, W. Jr., 1985: Vibration problems in engineering. Moscow. Mashinostroenie, 472.

14. Vobolis, J.; Albrektas, D., 2012: Evaluating the effect of finishing materials on viscous elastic properties of particle boards. Materials science. Kaunas University of Technology, Academy of Sciences of Lithuania. 18 (3): 262-266. https://doi.org/10.5755/j01.ms.18.3.2436.

15. Wagenführ, R., 2000: Holzatlas mit zahlreichen Abbildungen. München, Fachbuchverlag Leipzig im Carl Hanser Verlag, 707.

16. Wawro D.; Kazimierczak J., 2008: Forming Conditions and Mechanical Properties of Potato Starch Films. FIBRES \& TEXTILES in Eastern Europe Journal, 16 (6): 106-112.

17. Wood Handbook, 2010: Wood as an Engineering Material. Centennial Edition. Forest Products Laboratory. Wood Handbook-Wood as an engineering material. General Technical Report FPL-GTR-190. Madison, WI: U.S. Department of Agriculture, Forest Service, Forest Products Laboratory, 508.

18. *** EN 13183-2, 2004: Moisture content of a piece of sawn timber - Part 2: Estimation by electrical resistance method.

19. *** EN 323, 1999: Wood-based panels - Determination of density.

20. *** EN 408, 2012: Timber structures - Structural timber and glued laminated timber - Determination of some physical and mechanical properties.

21. *** EN 23270, 1999: Paints and varnishes and their raw materials - Temperatures and humidities for conditioning and testing.

\section{Corresponding address:}

Assoc. prof. DARIUS ALBREKTAS

Kaunas University of Technology

Faculty of Mechanical Engineering and Design

Studentu st. 56

LT - 51424 Kaunas, LITHUANIA

e-mail: Darius.Albrektas@ktu.lt 